probability of about 10 to 1 that the woman is not a heterozygote, and, combining the genetic and the biochemical information, the total relative probability is still about 10 to 1 that she is not a carrier. If such a young woman has a serum level of 2.5 units (logarithm 0.40) this is higher than that found in all but about $2 \%$ of controls, and about $20 \%$ of carriers have lower levels, so that the combined relative probability is about 10 to 1 that she is a heterozygote.

If the genetic probability had not been 1 to 1 but 3 to 1 against the woman being a heterozygote, then enzyme levels of 1.5 units and 2.5 units would give, respectively, combined relative probabilities of about 30 to 1 against and about 3 to 1 in favour of her being a heterozygote. A young woman taken at random from the population and with no relative with muscular dystrophy would have a genetic probability of only about 1 in 5,000 of being a carrier. So even if her enzyme level was 2.5 units, the total relative probability would still be about 500 to 1 against her being a carrier.

The number of women heterozygous for the genes for the mild sex-linked and autosomal recessive types who have been tested for creatine kinase levels is too small to establish reliable means and ranges. However, it is interesting that, though the mild sex-linked variety is clinically less severe than the autosomal recessive form, the enzyme levels of the carriers of the gene for the sex-linked form do not differ significantly from the levels in the carriers of the severe sex-linked form; while levels in the carriers of the gene for the autosomal form do not differ significantly from those in controls. This is intelligible on the Lyon hypothesis that, in women heterozygous for mutant genes on the X-chromosome, many cells will have as the active $\mathrm{X}$-chromosome the one which carries the mutant gene.

\section{Summary}

Serum creatine kinase levels, using the method of Hughes, were measured on three separate occasions on 21 control women, 17 women heterozygous for the gene for severe sex-linked muscular dystrophy, five women and two girls heterozygous for the gene for the mild sex-linked form, and five women heterozygous for the gene for the autosomal recessive form. The mean level in the control women was 1.31 units $(\mu \mathrm{M}$ creatine per ml. serum per hour at $37^{\circ}$ C.) and for the women heterozygous for the gene for severe sex-linked muscular dystrophy 4.02 units.

Using the logarithms of the enzyme levels to give more normal distributions the range for controls was 0.70 to 2.27 units and the range for heterozygotes for the gene for the sexlinked form was 1.50 to 8.93 units. About $90 \%$ of controls will have a mean level below 1.9 units and about $90 \%$ of heterozygotes will have a mean level above 1.9 units. The distribution of the logarithms of the enzyme levels may be used in combination with the available genetic information to estimate the relative probability that a woman is or is not a heterozygote. For example, assuming normal distributions of the logarithms of the levels, below a level of 1.5 units the relative probability, from the enzyme level, was more than 10 to 1 that the woman was not a heterozygote; above 2.5 units it was more than 10 to 1 that the woman was a heterozygote.

In the small series of women heterozygous for the mild sexlinked and autosomal recessive forms the creatine kinase levels in the former did not differ significantly from those in the severe sex-linked form, and creatine kinase levels in the latter did not differ significantly from those in the controls.

We are grateful to the members of the families of patients with muscular dystrophy, and to the controls, for providing repeated specimens of blood. We thank Dr. B. P. Hughes for demonstrating his method of creatine kinase estimation; Dr. H. Johnson and Dr. H. Blyth for sending samples of serum from Oxford and Leeds; Dr. P. D. Griffiths for telling us of unpublished work on the effects of exercise ; and Mrs. J. Shepherd for valuable technical assistance. We are particularly grateful to Dr. B. E. Clayton and Dr. J. A. F. Roberts, F.R.S., for advice and encouragement. One of us (K. M. W.) is indebted to the joint Research Board of the Institute of Child Health and the Hospital for Sick Children for financial help.

\section{REFERENCES}

Aebi, U., Richterich, R., Colombo, J. P., and Rossi, E. (1961-2). Enzym. biol. clin. (Basel), 1, 61 .

Blyth, H., and Pugh, R. (1959). Ann. hum. Genet., 23, 127.

Chung, C. S., Morton, N. E., and Peters, H. A. (1960). Amer. F. hum.

Clayton, B. E., Wilson, K. M., and Carter, C. O. (1963). Arch. Dis. Childh., 38, 208.

Dreyfus, J. C., and Schapira, G. (1961). Rev. franç. Etud. clin. biol., 6, 700 .

Griffiths, P. D. (1964). F. clin. Path., 17, 56.

Hughes, B. P. (1962a). Brit. med. F., 2, 963

(196.2b). Clin. chim. Acta, 7, 597.

Leyburn, P., Thomson, W. H. S., and Walton, J. N. (1961). Ann. hum. Genet., 25, 41.

Pearce, J. M. S., Pennington, R. J., and Walton, J. N. (1964a). F. Neurol. Neurosurg. Psychiat., $27,1$.

Neurosurg. Psychiat., 27, 1. 27, 181.

Richterich, R., Rosin, S., Aebi, U., and Rossi, E. (1963). Amer. 7. hum. Genet., 15, 133.

Schapira, F., Dreyfus, J. C., Schapira, G., and Demos J. (1960). Rev. franç. Etud. clin. biol., 5, 990.

\title{
Double-blind Trial of Bismuth Aluminate and Magnesium Trisilicate in Peptic Ulceration with Simultaneous Gastric Analysis
}

\author{
S. G. FLAVELL MATTS,*† M.B., CH.в., M.R.C.P.ED.; C. H. J. SWAN,* M.B., CH.B.; J. KELLEHER,* M.SC., A.R.I.C.
}

Brit. med. F., 1965, 1, 753-756

There is no general agreement on the best form of medical treatment for peptic ulceration, although most people are prepared to consider the medical management of gastric and duodenal ulcers together as "peptic ulcer" in spite of the fact that their aetiology may be somewhat different (Dragstedt, 1962 ; Avery Jones, 1964). It is accepted that the actual ulcer is caused by digestion of the mucosa by pepsin and hydrochloric acid, but the factors that allow this to happen are obscure. Excessive secretion of hydrochloric acid has been put forward as a likely cause, and it is partly on this basis that antacids are given in treatment. Other workers favour the idea that decreased tissue resistance is the basic cause of peptic ulcer and postulate many underlying factors influencing the decrease in resistance. Additional causes that have been given include excessive pepsin production, stress, hormonal dysfunction, and regurgitation of duodenal contents into the stomach (Spira, 1956, 1964 ; Sun, 1962 ; Dragstedt, 1962 ; Lancet, 1962).

In spite of this difference of opinion on aetiology, the most widely recommended form of therapy consists of modification

* The Royal Hospital, Wolverhampton.

† Present address: The Royal Marsden Hospital, London. 
of diet, rest, and "antacids." The most frequently used of these are magnesium or bismuth salts. The rationale for using bismuth salts has been strengthened of recent years by the discovery that they have good antipepsin action without much acid-neutralizing power (Stephens, 1953 ; Bateson, 1954, 1958). The importance of this has been increased by the American workers, who have shown that, in addition to pepsin, there may be several other acid proteases of gastric origin which will work at a higher $p \mathrm{H}$ (Hollander, 1962). These will not be influenced so much by neutralizing the gastric acidity.

Recent work has been carried out to test the validity of the hypothesis that pepsin-neutralization without much acidneutralization would be an effective form of treatment (Matts and Swan, 1964). This preliminary study revealed good clinical results, but little effect on the gastric contents in vivo, when bismuth aluminate (Bislumina, a powerful antipepsin compound) was employed as the therapeutic agent. In order to explore the possibilities of pepsin-neutralization further, it was decided to carry out a double-blind randomized clinical trial of magnesium trisilicate against bismuth aluminate, employing sequential analysis. At the same time gastric analysis would be performed on all the patients included in the trial to determine the effect of therapy on the gastric contents. This should therefore answer two questions: firstly, which of the two agents is clinically more effective ? and, secondly, what effect does treatment with either have on the in vivo gastric contents?

\section{Method}

Patients were admitted to the trial who were suffering with acute symptoms from a radiologically confirmed gastric or duodenal ulcer. They were given either magnesium trisilicate or bismuth aluminate by a method of random selection, a double-blind technique being employed so that neither doctor nor patient was aware of the treatment in use. The conditions were identical in each patient. Initial full assessment was made both clinically and radiologically, and then the trial began. An initial gastric analysis was performed in each patient, as follows:

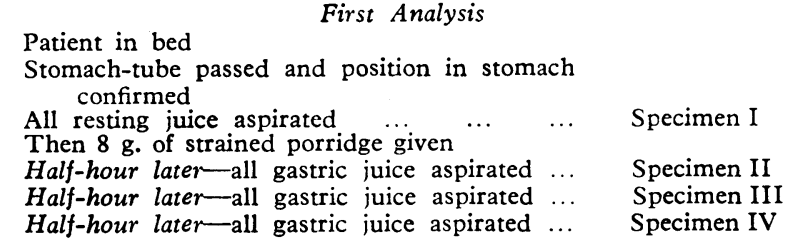

The next day the analysis was repeated as follows:

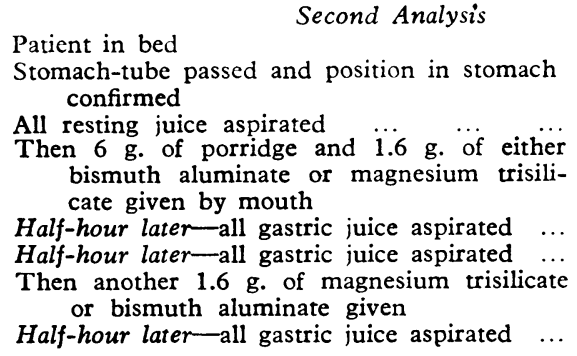

Specimen I

Specimen II

Specimen III

Specimen IV

The second analysis was repeated identically one month later (third analysis), after the patient had received treatment continuously for one month.

The patients, after their initial assessment and gastric analyses, were put on either $1.6 \mathrm{~g}$. of magnesium trisilicate before meals for one month or $1.6 \mathrm{~g}$. of bismuth aluminate before meals for one month. They were given no other treatment. They were kept in bed for the first two weeks but were allowed up the remainder of the time.
Final assessment was made clinically and radiologically at the end of the month. This assessment was carried out "blind" and was based on a points system. Points were awarded in each case after considering the following clinical features: the physical finding of abdominal tenderness; the patient's reports on the pain; the general well-being of the patient, with particular reference to appetite and psyche; the presence or absence of occult blood in the stools; the rise or fall in the haemoglobin; the presence or absence of nausea and vomiting. In addition, radiological studies were undertaken and measurement of the ulcer crater was carried out. The points were totalled up before and after treatment and the difference was noted in each case.

Patients were then compared according to a random pairing pattern determined before the start of the trial, and the results, as regards advantage to one or other preparation, were plotted on a sequential analysis chart, which was based on a design suitable for small trials (Armitage, 1954 ; Snell and Armitage, 1957 ; Watkinson, 1958 ; Matts, 1960). The advantages of using this design are that a significant result may emerge after a small number of patients have been included in the trial.

The specimens of gastric contents were analysed for both peptic activity and $p \mathrm{H}: p \mathrm{H}$ was measured using a glass electrode. Aliquots of the gastric juices were adjusted to $\mathrm{pH}$ 2.01 and 3.65 with normal $\mathrm{HCl}$ and/or $N \mathrm{NaOH}$, and maintained at these two $\mathrm{pH}$ values with equal volumes of $0.1 \mathrm{M}$ glycine and hydrochloric acid buffer $p \mathrm{H} 2.01$ and with $0.2 M$ sodium acetate and hydrochloric acid buffer $p H 3.65$ respectively. Peptic activity was assayed on these adjusted samples by a modification of the method of Hunt (1948).

In order to allow for possible incomplete aspiration of gastric contents at each analysis, the results were calculated as units per millilitre of gastric contents, and thus gave an estimate of the overall concentration of pepsin activity in the stomach contents at the time of analysis.

\section{Results}

The results were evaluated clinically and radiologically by the methods described. The two groups were then paired for sequential analysis by a predetermined randomized method and the results plotted on the prepared sequential analysis chart. From this can be seen a clear and statistically significant result in favour of the bismuth aluminate (see Graph), and the boundary of significance was reached after only six pairs of patients had been charted (the minimum number necessary).

The gastric analyses were carried out, and they were then examined for statistically significant changes, by comparing the means and the standard deviations of the various groups (see Table). In no case was there any evidence of significant change, in either $p \mathrm{H}$ or pepsin activity, after administration of the drug ; neither was there any evidence of a difference between the two groups. In fact, it appeared that treatment did not have a significant effect on the contents of the lumen of the stomach. This is in striking contrast to the marked clinical improvement obtained with bismuth aluminate.

\section{Discussion}

In considering and evaluating any method of treatment of peptic ulceration one is faced with a wide diversity of opinion on the underlying aetiology. This has led to many differing methods of treatment being used.

Antacid therapy is probably the most widely employed method in everyday clinical practice, and over 100 antacid preparations are in common use in Great Britain alone. However, much evidence has shown that they do not significantly change the gastric $\mathrm{pH}$ in vivo owing to inadequate dosage and rapid gastric emptying (Nicol, 1939 ; Sun, 1962; Schaub, 1963). In spite of this fact antacid therapy does bring about symptomatic relief and its use is justified for this reason (Avery 
Jones, 1964 ; Kay, 1964), although ulcer-healing has been shown to be unaffected even if the gastric $p \mathrm{H}$ is held above 4 throughout the 24 hours (Doll, Friedlander, and Pygott, 1956 ; Doll, Price, Pygott, and Sanderson, 1956).

Pepsin neutralization is an alternative method of treatment to be considered. As pepsin activity was thought to be reduced when the $p \mathrm{H}$ rises, it has been suggested that antacids will have a combined effect on acid and pepsin. For this reason some authorities have disregarded the action of pepsin from the therapeutic angle because it depends on a strongly acid medium and therefore control of acidity will obviously abolish it (Douthwaite, 1958). However, as control of acidity cannot be shown to occur with normal dosage of antacids in vivo, this is no longer valid. Another important factor is that recent studies of gastric function have indicated the possibility of there being several proteolytic agents in the gastric contents; cathepsin, gastricsin, parapepsin I and II (Hollander, 1962). These other proteolytic agents are active over a $p \mathrm{H}$ range of

\section{SEOUENTIAL ANALYSIS CHART}

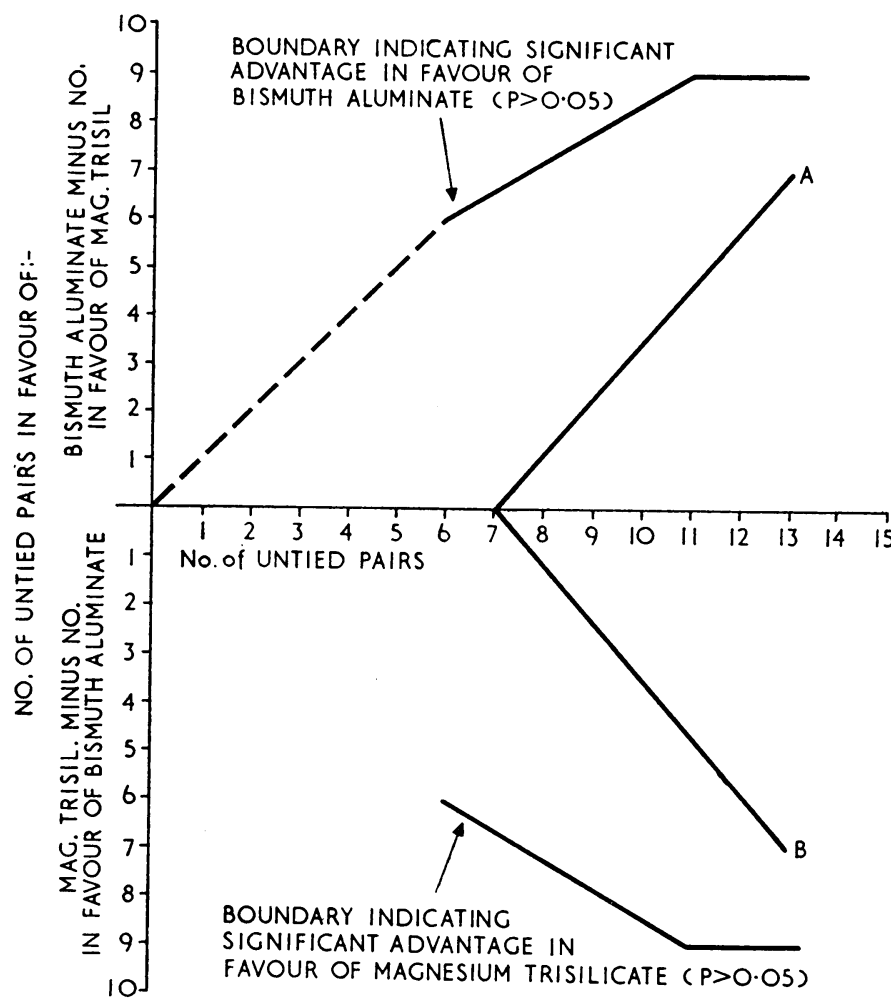

$A$ and $B$ ARE BOUNDARIES INDICATINC THAT SIGNIFICANT DIFFERENCES ARE UNLIKELY TO EMERGE BETWEEN THE TREATMENTS EMPLOYED
$1.8-4.5$, which is considerably higher than that of pepsin. It therefore seems that the role of pepsin and other gastric proteases must be seriously examined.

Bismuth aluminate has been shown in vitro to be a powerful antipepsin agent but a weak antacid and therefore should be of value in reducing gastric protease activity. Given in the normal therapeutic dosage, we have found it to have little effect on the gastric juices aspirated from the lumen of the stomach, and this finding may be explained by the increase in gastric secretion that sometimes occurs in response to neutralization of the stomach contents, or the rapidity with which the stomach empties.

It is interesting to consider the results of the trial reported here. Bismuth aluminate has been shown to have an undoubted clinical advantage when compared with magnesium trisilicate, although the control studies of gastric contents have shown that in all patients the therapeutic agents have had little effect on either the $p \mathrm{H}$ or the pepsin activity of the gastric juices. In order to explain this we must reconsider the whole causation of peptic ulceration. Recent thought has inclined towards an idea of a balance of forces-acid-pepsin challenging the defensive powers of the mucosa, with a shift away from the primary rule of hyperacidity and thus allowing for a process of autodigestion over a wide range of $p \mathrm{H}$ and the occurrence of ulcers in patients with a normal or low level of acid output (Hollander, 1962 ; Lancet, 1962).

The importance of mucosal resistance can perhaps be stressed and a concentration of thought into factors which can influence it may be justified. There is some evidence in comparative work with carrageenin, and also radiological studies with other bismuth salts, that a coating effect can be achieved over the gastric mucosa and in the crater of an existing peptic ulcer when therapeutic agents are given by mouth (Pygott, 1954, This coating effect may perhaps account for the good therapeutic results with bismuth aluminate due to a local antipepsin action at the site of the ulcer, thus preventing further autodigestion and encouraging healing by an increase in local tissue resistance.

This hypothesis would also explain the relief of pain achieved by antacids. If they had a similar coating action a temporary acid-neutralization would occur at the ulcer site, but owing to their lower antipepsin activity autodigestion would be only slowed and not abolished, thus accounting for their lack of power at speeding healing.

Much further light needs to be shed on the whole matter of the treatment of peptic ulceration. There are at present too many apparent contradictions. Antacids, found by experience to be of symptomatic and possible therapeutic benefit, do not really significantly affect the gastris acidity in vivo in the normally recommended doses. Antipepsin agents effective in vitro show little influence on gastric pepsin in vivo, although

\begin{tabular}{|c|c|c|c|c|c|c|c|c|c|c|}
\hline \multicolumn{11}{|c|}{ Bismuth Aluminate Group } \\
\hline $\begin{array}{l}\text { Fasting } \\
\frac{1}{2} \text { hour after } 8 \mathrm{~g} \text {. gruel }\end{array}$ & $\begin{array}{l}4 \cdot 1 \pm 2 \cdot 1 \\
2 \cdot 7 \pm 1 \cdot 6\end{array}$ & $\begin{array}{l}31 \cdot 0 \pm 21 \cdot 3 \\
30 \cdot 9 \pm 11 \cdot 6\end{array}$ & $\begin{array}{r}10 \cdot 5 \pm 10 \cdot 3 \\
10 \cdot 7 \pm 4 \cdot 1\end{array}$ & $\begin{array}{l}\text { Fasting } \\
\frac{1}{2} \text { hour after } 6 \text { g. gruel }+\end{array}$ & $5 \cdot 8 \pm 1 \cdot 8$ & $29 \cdot 4 \pm 26 \cdot 2$ & $11 \cdot 3 \pm 10 \cdot 0$ & $4 \cdot 1 \pm 2 \cdot 7$ & $27 \cdot 7 \pm 22 \cdot 9$ & $7 \cdot 9 \pm 4.9$ \\
\hline 1 hour after $8 \mathrm{~g}$. gruel & $2 \cdot 6 \pm 1 \cdot 5$ & $31 \cdot 7 \pm 16 \cdot 6$ & $9 \cdot 1 \pm 6 \cdot 1$ & $\begin{array}{l}1.6 \mathrm{~g} \text {. antacid } \\
1 \text { hour after } 6 . \mathrm{g} \text {. gruel }+\end{array}$ & $3 \cdot 2 \pm 1 \cdot 6$ & $32 \cdot 7 \pm 16 \cdot 1$ & $9 \cdot 9 \pm 7 \cdot 2$ & $3 \cdot 3 \pm 2 \cdot 0$ & $23 \cdot 7 \pm 17 \cdot 9$ & $8.9 \pm 7 \cdot 3$ \\
\hline $1 \frac{1}{2} \underset{\text { gruel }}{\text { hours after } 8 \mathrm{~g} .}$ & $3 \cdot 4 \pm 2 \cdot 1$ & $27 \cdot 8 \pm 20 \cdot 2$ & $10 \cdot 1 \pm 6 \cdot 5$ & $\begin{array}{l}1.6 \mathrm{~g} \text {. antacid } \\
\frac{1}{2} \text { hour after second } 1.6 \mathrm{~g} . \\
\text { antacid }\end{array}$ & $\begin{array}{l}3 \cdot 3 \pm 1 \cdot 4 \\
4 \cdot 3 \pm 2 \cdot 0\end{array}$ & $\begin{array}{l}42 \cdot 8 \pm 8 \cdot 2 \\
25 \cdot 0 \pm 18 \cdot 9\end{array}$ & $\begin{array}{l}17 \cdot 5 \pm 7 \cdot 1 \\
11 \cdot 7 \pm 8 \cdot 2\end{array}$ & $\begin{array}{l}4 \cdot 1 \pm 2 \cdot 5 \\
3 \cdot 8 \pm 2 \cdot 2\end{array}$ & $\begin{array}{l}28 \cdot 6 \pm 20 \cdot 1 \\
35 \cdot 7 \pm 25 \cdot 2\end{array}$ & $\begin{array}{r}9 \cdot 2 \pm 7 \cdot 4 \\
10 \cdot 8 \pm 7 \cdot 4\end{array}$ \\
\hline
\end{tabular}

\begin{tabular}{|c|c|c|c|c|c|c|c|c|c|c|c|}
\hline \multicolumn{12}{|c|}{ Magnesium Trisilicate Group } \\
\hline $\begin{array}{l}\text { Fasting } \\
\frac{1}{2} \text { hour after } 8 \mathrm{~g} \text {. gruel }\end{array}$ & $\begin{array}{l}4 \cdot 4 \pm 2 \cdot 6 \\
3 \cdot 1 \pm 1 \cdot 9\end{array}$ & $\begin{array}{l}25 \cdot 4 \pm 26 \cdot 9 \\
33 \cdot 3 \pm 18 \cdot 2\end{array}$ & $\begin{array}{l}10.6 \pm \\
10.9 \pm\end{array}$ & $\begin{array}{l}8 \cdot 5 \\
6 \cdot 6\end{array}$ & $\begin{array}{l}\text { Fasting } \\
\frac{1}{2} \text { hour after } 6 \text { g. gruel }+\end{array}$ & $4 \cdot 0 \pm 2 \cdot 7$ & $36 \cdot 7 \pm 20 \cdot 1$ & $9 \cdot 0 \pm 5 \cdot 0$ & $2 \cdot 8 \pm 2 \cdot 4$ & $26.3 \pm 18.8$ & $8 \cdot 9 \pm 8 \cdot 1$ \\
\hline 1 hour after $8 \mathrm{~g}$. gruel & $2 \cdot 5 \pm 1 \cdot 1$ & $37 \cdot 1 \pm 17 \cdot 1$ & $12 \cdot 3 \pm$ & $7 \cdot 7$ & $\begin{array}{l}1.6 \mathrm{~g} \text {. antacid } \\
1 \text { hour after } 6 \mathrm{~g} \text {. gruel }+\end{array}$ & $3 \cdot 8 \pm 2 \cdot 2$ & $34 \cdot 8 \pm 18 \cdot 4$ & $14 \cdot 6 \pm 7 \cdot 0$ & $2 \cdot 7 \pm 1 \cdot 7$ & $26 \cdot 6 \pm 17 \cdot 8$ & $13 \cdot 2 \pm 5 \cdot 0$ \\
\hline$\frac{1}{2}$ hours after $8 \mathrm{~g}$. & $2 \cdot 6 \pm 1 \cdot 9$ & $32 \cdot 6 \pm 15 \cdot 4$ & $9 \cdot 7 \pm$ & $4 \cdot 4$ & $\begin{array}{l}1.6 \mathrm{~g} . \text { antacid } \\
\frac{1}{2} \text { hour after second } 1.6 \mathrm{~g} . \\
\text { antacid }\end{array}$ & $\begin{array}{l}1.7 \pm 0.6 \\
1.9 \pm 0.6\end{array}$ & $\begin{array}{l}32 \cdot 9 \pm 13 \cdot 7 \\
31 \cdot 2 \pm 15 \cdot 1\end{array}$ & $\begin{array}{l}7 \cdot 4 \pm 3 \cdot 7 \\
7 \cdot 4 \pm 5 \cdot 2\end{array}$ & $\begin{array}{l}2 \cdot 6 \pm 1 \cdot 7 \\
1 \cdot 8 \pm 0 \cdot 6\end{array}$ & $\begin{array}{l}32 \cdot 7 \pm 13 \cdot 0 \\
37 \cdot 7 \pm 18 \cdot 3\end{array}$ & $\begin{array}{r}9.9 \pm 6.1 \\
11.6 \pm 5.3\end{array}$ \\
\hline
\end{tabular}


a striking improvement in patients with peptic ulceration follows their employment (Matts and Swan, 1964). An antisecretory agent (poldine) is recommended in treatment and shown to be of value (Douthwaite, 1958), although later work shows it to have no effect in reducing the gastric acidity in duodenal-ulcer patients taking a bland diet (Lennard-Jones, 1961).

Other interesting therapeutic agents are carbenoxolone disodium salt (Biogastrone) and stilboestrol. Both have been subjected to carefully controlled clinical trials in pepsin ulceration and have been clearly shown to be valuable (Truelove, 1960 ; Doll, Hill, Hutton, and Underwood, 1962), but the mode of action of each is not clear.

We would like to put forward the possibility of a local coating action as an explanation for the efficacy of bismuth aluminate in peptic ulceration, and consider that this might fit into current views on the causation of peptic ulcer by increasing the tissue-resistance component of the equation acid-pepsin versus the defensive powers of the mucosa. Certainly our in vivo gastric studies have thrown much doubt on whether the normal therapeutic dosage of either magnesium trisilicate or bismuth aluminate has any lasting or significant effect on the contents of the lumen of the stomach. In spite of this we have demonstrated considerable therapeutic benefit from their use.

\section{Summary}

A double-blind controlled trial has been carried out comparing bismuth aluminate with magnesium trisilicate in patients with peptic ulceration. The results were analysed by restricted sequential analysis and a clear clinical advantage to bismuth aluminate was seen. In vivo, gastric analysis of the patients in the trial shows that neither agent has a significant effect on gastric $p \mathrm{H}$ or pepsin activity in the lumen of the stomach. The possibility of a local coating effect of bismuth is suggested as an explanation of its clinical efficacy.

We would like to thank Drs. J. V. S. A. Davies, P. A. Thorn, and W. A. Hudson for allowing us to study patients under their care; Dr. G. Walters for his advice and co-operation; Mr. F. Leonard, of M.C.P. Pure Drugs, for his assistance and supplies of bismuth aluminate (Bislumina); and the sisters and nurses of the Royal Hospital for their co-operation.

\section{REFERENCES}

Armitage, P. (1954). Quart. F. Med., 23, 255. Bateson, P. R. (1954). Med. ill. (Lond.), 8, 370. - (1958). 7. Pharm. Pharmacol., 10, 123.

Doll, R., Friedlander, P., and Pygott, F. (1956). Lancet, 1, 5. Hill, I. D., Hutton, C., and Underwood, D. J. (1962). Ibid., 2, 793. - Price, A. V., Pygott, F., and Sanderson, P. H. (1956). Ibid., 1, 70. Douthwaite, A. H. Pygott, F.̈ and Sanderson, P. H. (1958). Proc. roy. Soc. Med., 51, 1063.

Douthwaite, A. H. (1958). Proc. roy. Soc. Med., 51, 1063.

Dragstedt, L. R. (1962). Ann. N.Y.
Hollander, F. (1962). Ibid., 99, 4.

Hunt, J. N. (1948). Biochem. F., 42, 104

Jones, F. Avery (1964). Brit. med. F., 1, 754.

Kay, A. W. (1964). Ibid., 1, 754 .

Lancet, 1962, 2, 1313.

Lennard-Jones, J. E. (1961). Brit. med. F., 1, 1071.

Matts, S. G. F. (1960). Lancet, 1, 517.

- and Swan, C. H. J. (1964). Proceedings of International Congress of Gastro-Enterology, Brussels.

Nicol, B. M. (1939). Lancet, 2, 881.

Nicol, B. M. (1939). Lancet, 2, 881
Pygott, F. (1954). Ibid., 1, 1314.

Pygott, F. (1954). Ibid., 1, 1314.

Schaub, K. (1963). Pharm. Acta Helv., 38, 15

Snell, E. S., and Armitage, P. (1957). Lancet, 1, 860.

Spira, J. J.' (1956). Gastro-Duodenal Ulcer. Butterworth, London.

- (1964). Lancet, 1, 613.

Stephens, R. L. (1953). F. Pharm. Pharmacol., 5, 704.

Sun, D. C. H. (1962). Ann. N.Y. Acad. Sci., 99, 104.

Truelove, S. C. (1960). Brit. med 7., 2, 559.

Watkinson, G. (1958). Ibid., 2, 1077.

\title{
Mass Miniature Radiography in Detection of Heart Disease
}

\author{
M. BARRY,* M.D., B.SC., M.R.C.P.I. ; H. A. FLEMING, $†$ M.D., M.R.C.P.
}

Brit. med. F., 1965, 1, 756-759

In recent years advances in the diagnosis and surgical treatment of congenital and rheumatic heart disease have given greater importance to their early recognition. In addition, prophylactic treatment can be given against recurrences of rheumatic fever or the occurrence of bacterial endocarditis. Where the cardiac abnormality is an insignificant one an early authoritative explanation of this may avoid many unnecessary restrictions and possible cardiac neurosis.

Many different screening techniques for early diagnosis of heart disease have been pioneered, particularly in the United States of America. Mass miniature radiography has been used in many centres to help in the detection of heart disease, and is usually run in conjunction with a survey for lung diseases. The use and value of this method has been reported by West (1946), Flancher (1948), Bostock and Morris (1952), Porte (1952), and Schwartz and Berman (1952).

Maclean and Rogen (1949) carried out a survey in Glasgow using $35 \mathrm{~mm}$. chest $x$-ray films. They had the advantage of prior knowledge of either a history of rheumatic fever or of heart disease. Of 34,918 persons $x$-rayed, 1,703 were recalled and 220 of these were found to have heart disease. The know-

* Consultant Physician, Ipswich Chest Clinic.

t Consultant Cardiologist, East Anglian Regional Hospital Board and Addenbrooke's Hospital, Cambridge. ledge of the history may account for the large number of recalls, but in some cases the history was found to be incorrect.

Mathisen et al. (1950), using 5 by 4 -in. ( 12.5 by $10-\mathrm{cm}$.) chest $x$-ray films, reported on the detection of heart disease in a selected group-namely, patients referred by their physicians with suspected thoracic disease.

Selzer et al. (1951) in their screening techniques used 35-mm. films. Suspected cases were recalled for fluoroscopic examination. If the cardiac outline was still thought to be abnormal these patients were recalled for investigation. This duplication seems unnecessary.

Morton et al. (1959a) used 70-mm. chest $x$-ray films, lead $\mathrm{V}_{3} \mathrm{R}$ of the electrocardiogram, and physical examination by a team of 13 cardiologists. They discovered 33 cases of heart disease among 6,300 children examined and all but seven of these were congenital heart lesions. The method was laborious and expensive and would seem impracticable on a large scale. Morton et al. (1959b) compared three methods of screening schoolchildren: the single lead $\mathrm{V}_{3} \mathrm{R}$ electrocardiogram, a miniature chest $x$-ray film, and a limited physical examination. Their conclusions were that none of these methods alone was satisfactory and that the minimum basic examination still consisted of a full physical examination, chest $x$-ray film, and electrocardiogram. 